\title{
Pandemi Sonrasi Dünyada Kapitalist Medeniyetin Eleştirel Muhasebesi
}

\author{
MUSTAFA ÖZEL
}

Özet

Pandemi-sonrası dünyada "hiçbir şeyin eskisi gibi olmaması" için ciddi bir kültür ve medeniyet muhasebesine ihtiyaç vardır. İnsanlık tarihinin üç kültürel zihniyetin ritmik teselsülü çerçevesinde geliştiğini düşünen Pitirim Sorokin, manevî faktörleri önemsemeyip sadece maddî ihtiyaç ve zevklerin tatminine odaklanan sensate (duyusal) zihniyetin insanlığı bir açmaza sürüklediğini; çıkış için idealistik bir zihniyet oluşumuna muhtaç olduğumuzu dillendirmişti. Aynı tarihsel dönemde Said Nursi'nin yazdıkları da Sorokin'i teyit eder niteliktedir. İnsanlık tarihinin başlıca sorunlarını Mahşerin Dört Atlısı (Savaş, İç Savaş, Kıtlık ve Salgın Hastalık) metaforuyla irdeleyen Immanuel Wallerstein, kapitalist medeniyete bazı bakımlardan olumlu not vermekle beraber, sorunların çözümsüz kaldığına işaret etmekte; kendisinden önce yazan Mills, Myrdal ve Galbraith gibi düşünürler de bu görüşü desteklemektedirler. Son bölümde bilimden sanata geçerek, Bob Dylan ve Yunus Emre'nin çözüm önerilerine yer verilmektedir.

Anahtar Kelimeler: Kapitalizm, Kültür, Medeniyet

Anahtar İsimler: Sorokin, Said Nursi, Wallerstein, Bob Dylan, Yunus Emre

11

Cocuk ve Medeniyet Cilt: 5 Sayı: 9 2020/1: 11-25

\begin{abstract}
- ARASTIRMA MAKALESI-

MUSTAFA ÖZEL, mustafaozel@sehir.edu.tr ORCID: https://orcid.org/0000-0002-5240-8281

Gelis Tarihi 18.06.2020 • Kabul Tarihi 27.07.2020 doi: https://doi.org/10.47646/CMD.2020.196
\end{abstract}

There is a need for serious cultural and civilizational assessment in the postpandemic world for "nothing to be as they used to be". Sorokin, a historian of culture in mid-20 ${ }^{\text {th }}$ century, who thought of human history as the rhythmic 
succession of three cultural mentalities, voiced the fact that the materialistic sensate mentality led the humanity into a cul de sac, from which exit can be possible only via embracing a new, idealistic mentality. The ideas of a traditional Muslim scholar of the same period, Said Nursi, seem confirming Sorokin. Macrosociologist Immanuel Wallerstein, who critically evaluated the major problems of the humanity in terms of a Christian metaphor of "The Four Horsemen of the Apocalypse" (War, Civil War, Famine, and Epidemics), assessed the capitalist civilization favourably on some accounts. However, his final assessment is negative, arguing that capitalism could not solve the major issues, and even worsened them. The ideas of some critical social scientists like Mills, Myrdal and Galbraith confirm his position. In the final section, passing from science to art, I tried to outline what two sages, Bob Dylan and Yunus Emre, offer as a possible way out of our dilemmas.

Keywords: Capitalism, Culture, Civilization

\section{Giriş}

Virüsler taçlanınca, insanoğlu ya diz çöküp köleleşir, ya vurdumduymaz olur, yahut "adam gibi" bir muhasebeye yönelir. Nefs muhasebesi ve çok daha önemli olarak da sistem muhasebesi! Bizim Yunus'un zihninde bir sinek bir kartalı nasıl kaldırıp yere vurabiliyorduysa, Batı dünyasının Yunus'larından biri sayabileceğimiz Bob Dylan'ın zihninde de bir virüs bir dünyayı kaldırıp vurdu yere. Yere çalınan dünya, konformizmi bir yana bırakıp, "başımıza gelen nedir?” sorusuna ciddi bir cevap aramalıydı. Yeni albümü "Rough and Rowdy Ways" vesilesiyle konuşan Nobel ödüllü 79'luk sanatçı, kendi fâniliğini değil, asıl insanlığın akıbetini merak ettiğini söylüyordu: "İnsan ırkının ölümünü düşünüyorum. Bu çıplak maymunun uzun, acayip sergüzeştini” (Dylon, 2020, 15 Haziran). Doksan iki yaşındaki ünlü eylemcifilozof Noam Chomsky de bu salgın vesilesiyle çocukluğunun atom bombalı acılı günlerine geri döndüğünü, çocukluk korkularının galiba tamamen yersiz olmadığını dile getiriyordu. Bugün Trump'ı dinlerken gözünün önüne o zamanki Hitler'in geldiğini ve bu fikirsiz sosyopatların insanlığın uçuruma doğru ilerlemesini hızlandırdıklarını belirten Chomsky, salgının diğer iki büyük tehdide nazaran daha kolay baş edilebilir bir felaket olduğuna da inanıyordu: Nükleer Savaş ve Küresel Isınma. Hatta salgın, "insanları nasıl

12

Çocuk ve Medeniyet 2020/1 bir dünya istediğimiz konusunda düşünmeye iteceğinden" belki de hayırlı olacaktı (Chomsky, 2020, Nisan).

Nasıl bir dünya istiyoruz? İnsanlık tarihinde şu veya bu yöneticiye, hatta siyasî yönetim biçimine karşı çıkıldığı elbet olmuştur. Klasik imparatorluk 
dönemlerinde köylü isyanlarından geçilmez. Fakat insanlığı çepeçevre kuşatmış olan bir sistemin muhasebesini yapıp, ona alternatifler sunmak yepyeni bir olguya benziyor. Daha salgının ilk günlerindeki yorumları medyadan takip ettiğimde, bu muhasebe işine Kapitalist medeniyetin mağdurlarından önce, efendilerinin el atacağından şüphem kalmadı. Nitekim, ilk sesini yükseltenlerden biri Klaus Schwab oldu, meşhur Davos zirveleriyle tanınan Dünya Ekonomik Forumu (WEF) kurucusu ve başkanı. Ne mi dedi, sıkı durun: Kapitalizme büyük bir "reset atmamız" gerekiyor, dedi: Küresel devlet borçları çok yüksek düzeylere ulaştı; işsizlik hızlanıyor; ekonomiler daralmaya devam ediyor. Buna rağmen Amerikalı milyarderlerin toplam servetinde artış var. Bazı ülkeler ve şirketler salgını, iklim ve çevreyle alakalı önlemlerin gevşetilmesinde bahane olarak kullanabilir. Birçok şirket de çalışanları ve paydaşlarıyla yeni ilişki biçimleri geliştirmeye bakacaktır. Bütün bunlar piyasa adaleti, eşitlik ve sürdürülebilirlik gibi sorunları mütemadiyen gündemimizde tutacaktır. "Büyük reset" işte bu çetin sorunlara çözüm arayışı olacak ve özellikle "Dördüncü Sanayi Devrimi"nin inovasyonlarını başta sağlık sektörü olmak üzere birçok alanda "kamu yararına" kullanma gayretiyle temayüz edecektir (Schwabb, 2020, 3 Haziran). Âmîn...

Sosyal bilimciler ne yazık ki "yüksek" iş çevrelerinin bu iyimser önerilerini sistemin mantığına uygun bulmuyor. Claude Levi-Strauss'un bilim dünyasına armağanlarından biri olan antropolog Philippe Descola, dünyayı kurtarma arayışı şöyle dursun, "biz insanlar, gezegenin virüsleri hâline geldik" diyor. Hocasının kavramsallaştırmasından hareketle, pandemiyi bir "bütünsel toplumsal olgu" olarak nitelendiren Descola, bu tür olguların toplumu sarsıp, "onun derin mahiyetini açığa çıkardığını” söylüyor. Pandemi bu bakımdan sanayi-sonrası kapitalizmin ana hatlarını ifşâ eden bir ayraçtır: "Kapitalizm bir salgın gibi yayılmaya devam etmektedir. Sistemi uygulayanları doğrudan öldürmese de, yer yüzünün tüm sâkinlerinin yaşam koşullarını uzun vâdede yok edecektir. Gezegenin virüsleri hâline gelmiş durumdayız." (Truong, 2020, 20 Mayıs). Hülasa, önce ciddi bir kültür muhasebesi, ardından da kapsamlı bir (kapitalist) medeniyet muhasebesi yapmalıyız ki, salgın sonrası için yapılan tekliflerin sahicilik yahut sahteliklerini kavrayabilelim.

13

Cocuk ve Medeniyet 2020/1

\section{Tarih Boyunca Kültürel Zihniyetler}

İnsanlık binlerce yıldan beri sel, fırtına, deprem, salgın hastalık, açlık ve savaş gibi onlarca büyük sorunla boğuşa geldi. Medeniyet bir bakıma bu sorunlara mümkün çözümler geliştirme arayışıydı. Fakat her medenî hamle

Pandemi Sonrası Dünyada

Kapitalist Medeniyetin Eleştirel Muhasebesi 
de yeni sorunları beraberinde getiriyordu. Medeniyetler yükseliyor ve düşüyorlardı; bir çizgi istikametinde sonsuzca ilerlemek söz konusu değildi. İlk olarak 19. yüzyıl sanayi çağının "Pozitivist" bilgin ve düşünürleri, bir önceki "Aydınlanma" çağından tevarüs ettikleri ilerlemeci bir bakışla, yakın bir gelecekte insanlığın çözülmemiş hiçbir sorununun kalmayacağını; dünya ve hatta evren hakkında bilinmesi gereken her şeyi bileceğimizi düşünmeye başladılar. Oysa, Kapitalizm küreselleştikçe karmaşıklaşıyor; evren de adeta keşfedildikçe genişliyordu! Bu karmaşıklık ve genişleme karşısında, bilimsel ve felsefî bilgimiz büyücü çırağının ecza dolabını andırıyordu: Ne ararsan bulunur derde devâdan gayrı! Çeyrek yüzyıl önce, çoğunluğunu fizikçilerin oluşturduğu bir grup Fransız bilimadamı tarafından yayınlanan, son derece bilimsel Cehalet Sözlüğü’nde, bilimin "bilgi alanları" oluşturmaktan daha fazla "bilgisizlik alanları" oluşturduğu kanıtlanıyordu (Cazenave, 1998). Anlıyorduk ki, başka şeylerin yanısıra bilimi de ortaya çıkaran "Kültür” ü tanımadıkça, neye uğradığımızı kavrayamazdık.

Kültür tarihçilerine göre, dünyayı derinleştirip anlaşılmaz kılan, çoğunlukla kendi kurgularımızdır. Kollektif çabalarımızın, birlikte varoluşumuzun eseri olan kültürel "zihniyetlerimiz". Pitirim Sorokin bütün insanlık tarihinin üç kültürel zihniyet arasındaki ritmik bir ilişki çerçevesinde biçimlendiğine inanıyordu. Birincisi, gerçekliği esasta gayr-ı maddî olarak gören ve manevî ihtiyaç ve gayeleri öne çıkaran Ideational (tasavvurî) zihniyetti. Bu manevî gayelere öncelikle bireyin fizikî ihtiyaçlarını en aza indirmek veya ortadan kaldırmak suretiyle, yani nefs murakabesi veya zühd tavrıyla erişilirdi. İkincisi, gerçekliği temelde maddî veya fizikî olarak algılayan, en önemli beşerî ihtiyaçların bedenle ilgili olduğunu söyleyen Sensate (duyusal, ihsasî) zihniyetti. Bu zihniyette hayr (iyilik), maddî ihtiyaçların maksimum tatmininde yatıyordu. Şiârı şöylesine sloganlarda ifadesini buluyordu: "Hayat kısadır. Ye, iç, eğlen!”. Bu kültürel zihniyet aynı zamanda hem tabiatı, hem beşer toplumunu yorumlama, aktif biçimde denetleme ve hükmetme arayışıyla temayüz ediyordu. Son olarak, bu ikisinin bir tür karışımı veya ikisinin ortasında yer alan üçüncü bir kültürel zihniyet vardı: Idealistic (ülkücü) zihniyet. Gerçekliği hem maddî hem manevî olarak algılayan, ihtiyaçlarla gayeler arasında denge kuran, hem fizikî hem manevî ihtiyaçların tatminine çalışan bir zihniyet. Sorokin'e göre, bu zihniyetler tarih boyunca birbirinin peşinden gelirlerdi; birinin ömrü tükenince, yerini diğerine bırakırdı. Çağdaş Batı medeniyeti de en az 500 yıldır genişlemekte

14

Cocuk ve Medeniyet 2020/1 olan Sensate zihniyetin etkisindeydi. Bu zihniyet artık son sınırlarına yaklaşıyordu ve yakında yok olacak, yerini Idealistic halefine bırakacaktı. Sorokin bu gelişmeyi sadece tespitle yetinmiyor, kalben arzu da ediyordu (Bkz. Sanderson, 1995). 
Sensate, yani beş duyuya öncelik veren, sadece maddî unsurları önemseyen zihniyet. Kapitalizm, işte bu zihniyetin eseridir. Tarih ve sosyolojinin projektörleri altında, Sorokin'in ilmî bir belagatle dile getirdiği bu hakikatı, aynı zaman diliminde, sadece tevarüs ettiği İslâmî kültürün imkânlarından yararlanan klasik bir medreseli Bediüzzaman Said Nursî kendine has üslubuyla şöyle ifade ediyordu: "Medeniyet-i hâzıra-i garbiye semavî kanun-u esâsîlere muhalif olarak hareket ettiği için seyyiatı hasenatına, hataları, zararları faidelerine râcih geldi. Medeniyetteki maksud-u hakiki olan istirahat-1 umumiye ve saadet-i hayat-ı dünyevîye bozuldu. İktisad ve kanaat yerine israf ve sefahat... ve sa'y ve hizmet yerine tembellik ve istirahat meyli galebe çaldığından biçare beşeri hem gayet fakir, hem gayet tembel eyledi.” İfadede ilk bakışta bir çelişki var gibidir. Kapitalizm, insanlık tarihinin en üretken sosyal sistemi değil mi? İnsanlığı nasıl fakir bırakmış, maddî saadetini gölgelemiş olabilir? İşte Bediüzzaman'ın cevabı: "Bedevilikte beşer, üç-dört şeye muhtaç oluyordu. O üç dört hacatını tedarik etmeyen on kişide ancak ikisi idi. Şimdiki garb medeniyet-i zalime-i hazırası su-i istimalât ve israfat ve hevasatı tehyic ve havayic-i zaruriyeyi zaruri hacatlar hükmüne getirip, görenek ve tiryakilik cihetiyle şimdiki medenî insan dört hacat yerine yirmi şeye bu zamanda muhtaç oluyor. $\mathrm{O}$ yirmi hacatı tam helâl bir tarzda tedarik edecek yirmi kişiden ancak ikisi olabilir. Onsekizi muhtaç hükmünde kalır. Demek bu medeniyet-i hazıra insanı çok fakir ediyor. O ihtiyaç cihetinde beşeri zulme, başka haram kazanmağa sevketmiş; biçâre avâm ve havass tabakasını daima mübarezeye teşvik etmiştir." Evet, sensate zihniyetin marifeti, arzuları kamçılayıp onları insanlar için birer ihtiyaç haline getirmesidir. Böylece insanlığın büyük bölümü, sadece bedensel zevklerin tatmini için uğraşan, bunların çoğunu da karşılayamadığı için (görece) yoksul kalan bir sürüye dönüşmüştür. “Kur'an'ın kanun-u esasisi olan vücub-u zekât ve hurmet-i riba vasıtasıyla avamın havassa karşı itaatini ve havassın avama karşı şefkatini temin eden o kudsî kanunu bırakıp burjuvaları zulme, fukaraları isyana sevketmeye mecbur etmiş; istirahat-1 beşeriyeyi zir ü zeber eylemiştir." (Kutlar, 1986).

15

Cocuk ve Medeniyet 2020/1

\section{Kapitalist Medeniyetin Bilânçosu}

Kültürel zihniyet muhasebesinden topyekün bir Kapitalist medeniyet bilançosuna geçelim. Çağımızda kapitalizmin dostları da çok, düşmanları da. Ayn Rand'a göre, tarihte hiçbir siyasî-ekonomik sistem değerini böylesine belagatle kanıtlamış ve insanlığa bu denli büyük faydalar sağlamış değildir (Rand, 1962, s. vii). Günlük tecrübe de Rand'1 teyit ediyor gibidir: "Dün"e kıyasla daha çok üretip tüketiyoruz; kişi başına milli gelirimiz her geçen gün artıyor; dedelerimiz çarık giyiyordu, biz fabrika malı deri

Pandemi Sonrası Dünyada

Kapitalist Medeniyetin Eleştirel Muhasebesi 
ayakkabılar giyiyoruz, at arabası yerine otomobil veya uçakla yolculuk ediyoruz, vesaire. Bu gelişme dünyanın her yerinde eşit bir düzeyde görülmeyebilir, ama genel olarak insanlığın maddî bakımdan "ilerlemekte" olduğu, su götürmez bir gerçek gibi geliyor insana. Ve görünürde, insanlığın büyük bölümü bu ilerlemeye can atıyor!

Günün birinde basit bir gerçeğin bizi amansız bir tarih muhasebesine mecbur ettiği an, sarsılıyor ve uykudan uyanıyoruz. Öyle deprem veya salgın hastalık gibi büyük olaylardan söz etmiyorum; mesela bir derginin ârif bir edebiyat hocasıyla yaptığı iki sayfalık bir konuşma, karşımıza bir anda devasa bir mesele çıkarıyor: Kapitalizm insanlığa gerçekten maddî bir ilerleme temin etti mi? Yoksa, büyüyen rakamlar sadece nüfusun çok küçük bir bölümünün iktidar tutkusuna mı yarıyor? Çeyrek yüzyıl kadar önce, popüler bir dergide, gerçek bir ârif olan edebiyat hocamız Orhan Okay Bey'e yöneltilen soru şuydu: "1940'lı yılların İstanbul'unda insanlar arası ilişkiler nasıldı, çocukluğunuz nasıl bir ortamda geçti?” Cevap çok kısa ve net: "İnsanlar birbirlerini tanırd1. Hangi evde kim var bilinirdi. Herkesin iyi veya kötü bir evi vardı. 1930'larda İstanbul'da çok az sayıda kiracı vardı. Anadolu'dan gelen işçilerin kaldığı bekâr odaları vardı. Bunun dışında kiracı kavramı yoktu" (Yılmaz, 1996) ${ }^{1}$. Kırk yıl sonraki (1970’ler) çocukluğumun Karakösessi de (Ağrı) aynen böyleydi. Ne kadar yoksul olursa olsun, evsiz bir aile düşünülemezdi. (Aile kurmanın adı "ev"lenmek değil miydi? Batı dillerinde evlenmek anlamina gelen marriage ise kocaya (Latince, maritus) tâbi olmak demekti!). Karaköse'de sadece Batı'dan gelen subay ve memurlar kiracı olurlardı; kiraya verilecek evlerin sayısı da çok sınırlıydı. Derken Türkiye amansız biçimde "ilerledi" ve sonunda insanların büyük bölümü işçi veya memur gibi sıfatlarla "bekâr odaları"na mahkûm edildi. Bugün büyük (metropolitan) şehirlerdeki nüfusun yaklaşık üçte ikisi kirada oturuyor. Maddî ilerleme bu mudur?

Amerikalı serazat sosyolog C. Wright Mills, kırk yıl kadar önce, insanların, "özel hayatlarının bir dizi tuzaktan ibaret olduğu duygusuyla" yaşadıklarını söylüyordu. Bu tuzağa yakalanmış olma duygusunun altında, toplumların bizzat yapılarında meydana gelmekte olan devasa gayrışahsî değişimler yatıyordu. "Çağdaş tarihin gerçekleri aynı zamanda münferit erkek ve kadınların başarı veya başarısızlıklarına dair gerçeklerdir. Bir toplum sanayileştiği zaman, köylüler işçi olur; feodal bey ya tasfiye olur veya işadamlığına soyunur. Sınıflar yükselip düştüğü zaman, insanlar iş bulur

1 Vurgular benim. Tasvirin manevî veçhesini tartışma dışı bırakıyorum. Yoksa, sadece "herkesin birbirini tanıyor olması" bile kişi başına millî gelirin bilmem kaç katına çıkmasına galib değil midir? 
veya işsizleşir; yatırım haddi yükselip düştüğü zaman, insanlar yeniden cesaretlenir yahut ümitsizliğe kapılır. Savaş patlak verdiğinde, sigortacı roket mühendisi olur; mağaza memuru ise radarcı; evli hanımlar yalnız yaşar, çocuklar babasız büyür. Ne bireyin hayatı, ne de toplumun tarihi, her ikisini birden anlamadan anlaşılamaz" (Mills, 1970, s.9). Bireyin hayatı, toplumun tarihi. Topyekün bir tahlil yapmadan asla anlaşılmayacak gerçekler. Fakat böyle bir tahlil yapılabilir mi? Daha açık söylersek, içinde yaşanılan bir tarihsel sistemin bilançosu çıkarılabilir mi? Kapitalizm, başlangıcından beri, erdem ve kötülükleri tartışılagelen; bu yönüyle belki de benzersiz bir sistemdir. Bir yanda, onun son derece eşitlikçi, dolayısıyla da eski toplumsal barışı ve (eşitsizliğe dayalı) cemaat ahengini bozucu olduğunu söyleyen kritikçiler var; diğer yandaysa, bütün çıkarların uyum içinde olduğu efsanesinin altında çok ileri bir eşitsizliğin yattığını ileri süren kritikçiler. Immanuel Wallerstein ikinci gruba mensup seçkin bir sosyal bilimci. Kapitalist medeniyetin mükemmel bir bilançosunu yapıyor. Kısaca gözden geçirelim (Wallerstein, 1995):

Beşer hayatının başlıca maddî sefaletleri nelerdir? Hrıstiyan tasavvuru "Mahşerin Dört Atlısı" diye nitelendirdiği felaketleri şöyle sıralar: Savaş, İç Savaş, Kıtlık ve (salgın hastalık veya vahşî hayvanların sebep olduğu) Ölüim. Bu dört atlı dünyaya dehşet salan, barış ve huzuru bozan, insanları zevk ve tatminden alıkoyan mazarrat-ı dünyevîyedir. Wallerstein'e göre, dünya dinleri bu felaketler karşısında insanoğluna mümkün olan her teselliyi sunmaya çalıştılar, ama tam bir siyasî (yani, dünyevî) çözümün olmadığını da ihsas ettirdiler. Mesiyanik bir çağ (mesela, Mehdi) gelinceye veya bir şekilde tarihin ötesine geçilinceye kadar, bu kötülükler kaçınılmazdı. Kapitalist medeniyet ise "tarih içinde tarihin ötesine geçme" iddiasına sahip olan ilk medeniyettir: Kaçınılmaz kötülük problemini çözen, yeryüzünde Tanrı'nın krallığını kuran, sözün kısası, Mahşerin Dört Atlısını alteden bir medeniyet. Kapitalizmin savunucuları, işin başından beri, Sistemin, sınırları dahilinde yaşayan bütün insanların "temel ihtiyaçlarını" karşılayabildiğini iddia edegeldiler. Anahtar kavramları "üretimin verimliliği” idi. Bu sayede toplumsal servet muazzam ölçüde arttırıldı. Bu servet eşitsiz bir tarzda bölüştürülmüş olsa bile, herkesin daha önceki tarihsel sistemlerde mümkün olan seviyenin üzerinde bir pay alması teminat altına alınabildi. "Görünmeyen El"in marifetiydi bu. Kapitalist sistem bu yüzden daha önceki sistemlerden farklı ve üstün olmakla kalmıyor, biricik 'doğal' sistem olarak resmediliyordu.

17

Cocuk ve Medeniyet 2020/1
Ayn Rand'a göre, temel mesele "insanın hür olup olmadığı"dır ve insanlık tarihinde insanın hür olabildiği tek sistem kapitalizmdir. "Kapitalizm, mülkiyet dahil olmak üzere birey haklarının tanınmasına dayanan, bütün 
mülkiyetin kişilere ait olduğu bir sosyal sistemdir. Kapitalist toplumda bütün beşerî ilişkiler ihtiyarîdir. İnsanların, başkalarının fikirlerine uymama hakları vardır. Bu hakkı koruyan ve uygulamaya sokan şey, özel mülkiyet kurumudur. Bu hak ve bu kurum, insanoğlunun en değerli niteliğine giden yolu açık tutar: Yaratıcı zihin" (Rand, 1962, s.19). Kapitalizm ile, Rand'ın topluca "kollektivizm" diye nitelendirdiği bütün diğer sistemler arasındaki büyük ve kapatılamaz fark buydu. Kulağa hoş gelse de, teoride herkesin mülk sahibi olabildiği, ama uygulamada insanların onda dokuzunun özel mülkiyetten mahrum edildiği bir sosyal sistemde "başkasının fikrine karşı çıkma" hakkı ne ölçüde korunabilirdi? Bu bağlamda, sanayi toplumunun işçisi, mesela Orta Çağ toprak kölesinden ne kadar daha hürdü? Bunların hiç biri tarihsel veriler ışığında tartışılmıyordu. Rand'ın ima ettiği şey, önündeki engelleri kaldırdığımız “yaratıcı zihin”in, Mahşerin Dört Atlısı'na galebe çalmamızı tarihte ilk defa imkân dahiline sokmuş olduğuydu.

Peki bunun kanıtı nedir? Kadîm kötülüklerin yokedilmiş (ve yerlerine yenilerinin getirilmemiş) olduğunu nereden biliyoruz? Cevap basit: Günlük tecrübemizden. Etrafınıza bakın bir: Modern dünya, bilinen bütün dünyalardan daha zengin değil mi? Teknolojik ilerleme baş döndürücü değil mi? Herkesin hâli vakti eskiye nazaran daha iyi değil mi? Daha da önemlisi, kapitalizmin tam uygulandığı ülkeler en zengin ve ekonomik bakımdan en ileri ülkeler değil mi?

Birinci kareye geri döndük: Maddî bir ilerleme var, ama bu ilerleme Mahşerin Dört Atlısı ile başa çıkmamıza gerçekten yaradı mı? Yoksa, atlılar koşularını sürdürürken, onlara yeni atlılar mı katıldı? Tek tek gözden geçiriyor Wallerstein:

\section{Kapitalizm ve Hastalık}

Kapitalist medeniyet salgın hastalık, veba yahut vahşi hayvanların yol açtığı ölümleri (topyekün ortadan kaldırmamış olsa bile) ertelemiş veya azaltmış mıdır? En geniş anlamda sağlık ve hıfsızsıhha meselesidir bu. On dördüncü yüzyılda Avrasya karakütlesi Kara Ölümün (veba) pençesindeydi. Fazla güvenilir olmayan tahminlerimiz, etki altındaki bölgede nüfusun üçte birinin kırıldığını gösteriyor. Dünya tarihindeki ilk yaygın hastalık değildi bu şüphesiz; ancak, bu ölçüde yaygınlaşan son hastalık olmuşa benziyor. Başlıca şu iki sebepten: Birincisi, birey koruma altına alındığı için. Tıb bilgisi 2020/1 öylesine ilerleme kaydetti ki, bu gibi hastalıkların başlamasını (mesela aşı sayesinde) nasıl önleyebileceğimizi veya, bir kere insanlar hastalığı kapmışlarsa, etkisini nasıl en aza indirebileceğimizi daha iyi biliyoruz. İkincisi ise, topluluk koruma altına alındığı için. Daha iyi bir kamu sağlığı 
ortamını nasıl meydana getirebileceğimizi ve ayrıca hastalığın yayılmasını sınırlayacak teknikleri öğrenmiş bulunuyoruz.

Bunlar olumlu gelişmeler. Ama bilançonun bir de pasif tarafina bakmalı değil miyiz? Zıt yönde seyreden en az üç olgu var. Evvela, bizzat kapitalist dünya-ekonominin genişlemesinin bir parçası olan taşımacılıktaki teknolojik ilerlemeler yüzünden, parazitik gen havuzlarının karışmasının mahvedici sonuçları olmuştur. Bu en açık biçimde 1500 ila 1700 arasındaki okyanus aşırı mübadeleler örneğinde incelenmiş bulunuyor. Kuzey ve Güney Amerika'nın yerli nüfuslarının üçte birden fazlası bu süreçte kırılmıştır. Benzer hadiseler Okyanusya ile Afrika, Asya ve Avrupa'nın ücra köşelerinde de vuku bulmuştur. Güvenilir bir tarihçinin tespitleri şöyledir: "Okyanus seferlerinin başlattığı bu yeni mikroparazitik rejim bir felaket oldu. Avrupalı ve diğer medenî nüfuslarla temas ağır ölümlerle sonuçlandı. Bu ölümler yeryüzünün birçok yerinde (Kuzey Amerika, Avustralya, Güney Afrika, Sibirya) verimli toprakların boşalmasına ve böylelikle buralara Avrupalıların yerleşmesine yol açtı" (McNeill, 1992, s.115).

İkinci olarak, sadece son yarım yüzyılın tıbbî araştırmaları, kapitalist medeniyetin parçası olan ekonomik teknolojilerle doğrudan bağlantılı çevre değişmeleri yüzünden kaç hastalığın hakikatte sayıca arttığını vuzuha kavuşturmaktadır. Üçüncüsü, yerkürenin dört bir yanındaki şiddetli nüfus genişlemesinden ötürü tamamen yeni hastalık örneklerinin ortaya çıkıyor olması gayet mümkündür. AIDS (ayrıca SARS, Covid-19) ve benzeri yeni salgınlarda başlıca faktör bu olabilir. Tıbbî ilerlemeler sayesinde "uzatılmış" ömürlerin sayısı ile ani parazitik mübadeleler yüzünden "başlaması engellenmiş” ömürleri nasıl karşılaştıracağız? İkincisini rakamla ifade etmek zor olduğundan, karşılaştırmadan vazgeçebiliriz; ama en azından değerlendirmenin basit ve tek yanlı olmadığını anlamamız lâzım. Dünya sisteminin daha fazla sanayileşmiş bölgelerinde çocuk ölümlerinin önemli ölçüde azalmış olduğu açıktır. Yirminci yüzyılda Güney bölgelerinde de azalmışa benziyor, ancak bunun sadece dünya ekonomisinin genişleme dönemlerinde mi olduğu daha az açıktır. Sanayi ülkelerinde, tıp teknolojisindeki ilerlemeler sayesinde, altmış yaş ve üzerindekilerin hastalıklara dayanma yeteneklerinin önceki dönemlere göre arttığını biliyoruz. Ortalama ömür süresinin uzaması büyük ölçüde bu iki sebepledir: Çocuk ölümlerinin azalması ve altmışın üzerindekilerin daha uzun yaşaması. Çocukların altmış yaşa -öncesine göre- daha rahat ulaşıp ulaşmadıklarından ise çok daha az eminiz. Yeni salgınların rakamları topyekün değiştirip değiştirmeyeceği ise şüphesiz bilinemez. Fakat, hastalığa karşı mücadelede, her ne kadar başarısı coğrafi bakımdan eşitsiz gözüküyorsa da, Wallerstein kapitalist medeniyete muvakkaten olumlu not verebiliriz diyor. Peki, ya

Pandemi Sonrası Dünyada

Kapitalist Medeniyetin Eleştirel Muhasebesi 
açlığa karşı mücadelede? Kıtlık, bu üretim cenneti (?) medeniyette eski zamanlara göre daha az şiddetli bir tehlike midir?

\section{Kapitalizm ve Açlık}

Kapitalizm gibi kazanç ve dolayısıyla üretim-temelli bir sosyoekonomik sistemin aynı zamanda ciddi bir sefalet ve açlık tehlikesine yol açmış olması bir çelişki midir? Üstelik bu tehlike orta vadede sadece sanayi-dışı (yani sömürülen) bölgelerle sınırlı kalmayacak ve bizzat sanayi toplumlarını da pençesine alacak gibi gözüküyorsa? Kapitalizm-öncesi çağlarda insanlığın temel problemi üretimi her yıl etkileyebilen kısa vadeli hava değişimleriydi. Taşımacılık sistemleri zayıf, uzun vadeli depolama imkânları sınırlı ve bireylerin para rezervleri hemen her yerde ender olduğundan, yiyecek maddelerinin yerel arzındaki herhangi bir önemli azalma çabucak büyük sorunlara yol açabiliyordu. Teknolojik ilerlemeler bugün dünyanın birçok (belki de çoğu) kısımlarını öngörülebilir kısa vadeli hava sapmalarına karşı koruma altına almış bulunuyor. Fırınlarımızın yarın ekmek pişireceğinden emin gibiyiz.

Peki, ya öbür gün? Ya çevre şartlarındaki orta vadeli değişimler? Bize kısa vadede doğal biyosiferik şartlara müdahale imkânı veren aynı teknolojik ilerlemeler, orta vadede biyosiferik şartları altüst etmiştir. Ormanların yok edilmesi, savana bölgelerinin çölleştirilmesi gibi gelişmeler bütünüyle toplumların ve onların uzun vadeli yiyecek arzlarının mütemadi imhasını içermektedir. Yirminci yüzyılda o kadar ileri giden kimyasal-biyolojik kirlenmenin yol açtığı zayiatı değerlendirmekten bile aciziz. Şayet ozon tabakası daha fazla tüketilirse, canlıların (hem doğrudan, hem de yiyecek arzı üzerindeki etki yoluyla dolaylı) imhası devasa boyutlara ulaşır. O halde, bir yanda, toplam üretimde ve yiyecek üretiminin üretkenliğinde çarpıcı bir genişleme; diğer yandaysa, olağanüstü ölçüde çarpıtılmış bir dağıtım sistemi meydana gelmiştir. Bu durum dünya nüfusunun çoğunluğu, özellikle tabandaki yüzde 50-80 arası kısım için kısa vadeli tehlikelerin yerine orta vadeli tehlikeleri ikame etmiştir. Myrdal'a göre, dünyadaki sefalet sorununu tartışan hemen hemen bütün insanların sistemli biçimde görmezden geldikleri temel bir gerçek, bütün bilginin, tıpkı bütün cehalet gibi, fırsatçı bir yönde hakikatten sapmaya meylettiğidir. Geçmişteki bir düşünürü değerlendirirken, onun "yaşadığı çağın ürünü” olduğunu söylemekten zevk duyarız; fakat nedense kendimiz için aynı şeyi düşünmez, hangi etkilerin altında fikir "ürettiğimizi” hesaba katmayız. Açlık ve sefalet hakkında söylenegelenlerin büyük kısmı "sömürgeci söylemi"dir. Efendilerin diliyle konuşuyoruz (Myrdal, 1972, s.72). 
Mesela, "Üçüncü Dünya”nın sefaletini genellikle doğal şartlara bağlamaya meylederiz. Galbraith, bunun temelsiz bir mit olduğunu söylüyor: "Japonya yoksul bir ülke olsaydı, sefaleti doğal şartlarında aranabilirdi. Dağlarla kaplı, verimli toprağı çok az, maden yatakları kıt, petrolü yok bir adacıklar kümesinde milyonlarca insan yaşıyor. Japonya'nın katastrofik derecede ürkütücü doğal donanımından hiç söz edilmez, çünkü ülke zengindir. Şayet yoksul olsalardı, Tayvan, Hong Kong, İsrail ve Güney Kore hakkında da benzer sözler edilecekti." (Galbraith, 1980, s.15). Yirminci yüzyılın bu büyük iktisatçısı son derece haklıdır: Açlık ve sefalet, doğal durumdan değil, Kapitalist sistemin adaletsiz işleyiş̧inden kaynaklanıyor. Ve bu işleyiş, doğal dengeyi her geçen gün sarstığından, orta ve uzun vadede bizzat efendiler için yıkıcı olma tehlikesini de içinde barındırıyor. Akıl alır gibi değil ama, insanlık tarihinin üretim şampiyonu kapitalist medeniyete açlıkla bağlantılı "hâl ve gidiş"ten geçer not vermek mümkün gözükmüyor.

Ya iç savaş ile "uluslar arası" savaşın durumu?

\section{Kapitalizm ve Savaş}

Kapitalist medeniyette iç savaşlar azaldı mı? Ne gezer? Wallerstein, "iç savaş"ın kapitalist dünya-ekonominin bir icadı olduğunu söyleyecek kadar ileri gidiyor. Şehir bölgelerinde toplumsal bakımdan ayrı "halklar" şeklinde tanımlanan grupların karışım ve yakınlığının çok ileri bir dereceye ulaştığı bir sistemdeki yapay (inşâ edilmiş) "halk" ile yapay “devlet” arasındaki karmaşı ilişkilerin eseridir iç savaş. Tesadüfî değildir bu; aksine kapitalist dünya-ekonominin içkin yapılanmasından çıkmaktadır. Bunları premodern dönemlerdeki taht kavgalarıyla karıştırmak büyük bir yanlışlıktır. Kapitalist dünya-ekonomi optimal işleyişi için, belirli coğrafî mahallerde işgücü ihtiyacını karşılamak üzere insanların (cebrî veya ihtiyarî) olarak yaygın ve kesintisiz muhaceretine ihtiyaç duyar. Bunun yanısıra dünya işgücünü etnikleştirir, öyle ki, herhangi bir mahalde nüfusun çeşitli etnik gruplanmalara ayrıldığı görülür. Böyle bir gruplanmanın işareti ister deri rengi, ister dil, din veya başka bir kültürel inşâ olsun, vaka budur. Bütün zamanlarda, hânelerin (yerel tarzda tanımlanan) etnik tabakaları ile meslekî ve sınıfsal yerleri arasında yüksek bir karşılıklı ilişki var gözükmektedir. Tabiatıyla ayrıntılar, yani etnik sınırların tanımları, hangi etnik grubun hangi meslek tabakasıyla örtüştüğü vs. mütemadiyen değişmektedir; fakat tabakalaşma ilkesi kapitalist dünya-ekonominin kalıcı bir veçhesidir; hem genelde emek maliyetlerini düşürmeye, hem de devlet yapılarını gayrımeşrulaştırma arayışlarını denetim altında tutmaya yaramaktadir.

Pandemi Sonrası Dünyada

Kapitalist Medeniyetin Eleştirel Muhasebesi 
$\mathrm{Bu}$ etnikleştirme süreci herhangi bir bilanço bakımından açık bir olumsuzluk demektir. Hem yüksek ve aşağı etnik tabakalar arasında, hem de aşağı kademedeki etnik tabakaların kendileri arasında sürekli bir mücadelenin yapısal temelini meydana getirmektedir. Dünya-ekonominin çevrimsel inişlerinde bu mücadeleler şiddetlenmeye meyletmektedir. Burada önemli unsur, dünya işgücünün etnikleştirilmesinin bir ırkçılık ideolojisine ihtiyaç duymasıdır: Bu ideoloji ile dünya nüfusunun büyük parçaları alt sınıflar veya aşağı varlıklar diye tanımlanmakta ve dolayısıyla siyasal ve toplumsal mücadeleler neticesinde kısmetlerine düşen her ne ise "ona müstehak oldukları" belirtilmektedir. Bu "iç savaşlar" zamanla azalmamış, aksine yirminci yüzyılda daha baskıcı ve ölümcül hale gelmiştir. Cari dünyasistemimizin bilançosunda çok büyük bir eksidir bu.

Savaşa gelince... Devletler veya toplumlar arasında savaş bütün tarihsel sistemlerde var olmuşa benziyor. Yani sadece modern dünya-sisteme özgü bir fenomen değildir. Ne var ki, modern ekonomik ve siyasal yapılar savaşın kapsam ve mahiyetini büyük bir dönüşüme uğratmış, savaş mağdurlarının sayısını akıl almaz boyutlara ulaştırmıştır. Hiroşima'ya atılan bir tek bomba pre-modern zamanlardaki bütün savaşlarda ölen insanlardan daha fazlasını yok etmiştir. Orta Doğu'yu bir baştan öbürüne yarıp geçen Büyük İskender yıkıcılıkta Körfez Savaşı'nın Irak ve Kuveyt üzerindeki etkisiyle boy ölçüşemez. On dokuzuncu yüzyılın ikinci yarısından itibaren Avrupa ülkelerinin erkek nüfuslarının büyük bölümü savaş için eğitilmiş ve cepheye sürülmüştür. "Sadece uzak geçmişteki barbar toplumların vasfi olan, her insanın bir asker olması ülküsü, yeryüzünün teknolojik bakımdan en ileri ülkelerinde gerçeğe dönüşmüştür” (McNeill,1983, s.223). Her bireyin asker olduğu bir dünyada, artık hiç kimse güvenlik altında değildir. Savaş hususunda kapitalist medeniyetin bilançosuna olumlu not vermek mümkün gözükmüyor.

\section{Bob Dylan'1 Yunus'la Tamamlamak}

Yazının başında "İnsan ırkının ölümünü düşünüyorum. Bu çıplak maymunun uzun, acayip sergüzeştini” diyen 79'luk Bob Dylan, insanın temelde değişmediğine inanan bir sanatçıdır. Kırk yıl kadar önce (1983), güneş altında yeni bir insan yok, diyordu: "Sezar, İskender, Nabukadnezar, Baal, Nemrut.. dün olduğu gibi bugün de aramızdalar". Gene yıllar önce "I have no sense of time" (zaman duygum yok) diyen Dylan, tıpkı Hamlet veya Yeats gibi, zamanın çizgisel değil çevrimsel olduğuna inanıyordu. Geçmiş, geçip gitmezdi; sanat ve edebiyatta "her dem yeniden" can bulurdu (Daniel, 2020, 13 Haziran). "My Own Version of You" şarkısında, yeni bir insan 
yaratan kurgu kahraman Frankenstein'a özeniyor; kurtuluşu kendi eseri olacak bir robottan umuyordu:

Yaz boyunca ve tâ Ocak ayına kadar

Dolaştım morg ve manastırları

Gerekli vücut parçalarını arıyorum

Kol ve bacak, ciğer, beyin ve yürek

Ah, yeni bir insana can vermek,

Bunu yapmayı diliyorum

Senin Ben versiyonunu yaratmak istiyorum!

Peki, sanatçı bu arayışında başarılı olabiliyor mu? Bir umut var mı? Ne yazık ki, hayır demeye getiriyor Dylan; popüler sinema yıldızlarının göz boyayıcı atılganlıkları, bizi oyuncaklarıyla oynayan bir çocuğa dönüştürüyor ancak:

Kesikyüz Al Pacino ve Baba Brando'yu alıp

Bir kazanda karıştırıp robot bir komando yapacağım

İşi doğru yapıp kafayı da düzgün koydum mu

Yarattığım yaratık tarafından kurtarılacağım.

Bob Dylan'ın umutsuz girişimine karşılık, "bir sineğin bir kartalı kaldırıp yere vurmasına" sahiden şahit olduğunu söyleyen Yunus Emre, insanın nasıl yaratıldığını kavrayabilirsek, kurtuluş yolunu da bulabiliriz diyor. Anayurdu Cennet'ten dünya sürgününe gönderilmiş olan insanın, hakiki vatanına dönebilmesi nasıl ve niçin yaratılmış olduğunu kavramasına bağlıdır. Türkçe nasihatnâmelerin şâhı olan Risalet'ün-Nushiyye'den okuyalım:

Padişâhın hikmeti gör neyledi

Od u su toprag u yile söyledi

Bismillâh diyüp getürdi topragı

Ol arada hâzır oldı ol dagı

Topragıla suyı bünyâd eyledi

Ana Adem dimegi ad eyledi

Yil gelüp ardınca depitti anı

Andan oldı cism-i Adem bil bunı

Od dahı geldi vü kızdurdı anı

Çünki kızdı cisme ulaşdı cânı

Bu beyitlerde, varlığı oluşturan dört unsurun (anasır-ı erbaa) işlevlerini görüyoruz: Toprak ile su birbirine karıştırılıyor; rüzgâr bu oluşumu

2 Bu şiirin, Silicon Vadisi'nden Tabiat'ın bağrına dönen bir Facebook yöneticisi ile bir Mustafa Kutlu hikâyesi bağlamında tahlili için bkz. Mustafa Özel: Roman Diliyle İş Hayatı, İstanbul: Küre, 2019, s. 131-137.

Pandemi Sonrası Dünyada

Kapitalist Medeniyetin Eleştirel Muhasebesi 
hareketlendiriyor, ateş ise kızdırıyor. Hazret-i Âdem böylece varlık âlemine adım atıyor. Peki bu dört unsurun simgelediği ana nitelikler nelerdir? Yunus Emre'nin cevabı mükemmeldir:

Topragıla bile geldi dört sıfat

Sabr u eyü hû tevekkül mekremet

Evet, toprağın simgelediği sıfatlar sabır, iyi huy, tevekkül ve mekremettir (izzet, ikram). İnsan sabırla toprağı işler, hemcinsleriyle (ve toprakla) iyi geçinir, Allah'a güvenip dayanmayı terk etmezse, toprak ona ikramda bulunur; onu besler ve ayakta tutar. Onu böylece başı dik hâle getirip izzetli kılar. Peki su neyi simgeler?

Suyıla geldi bile dört dürlü hâl

Ol safâdur hem sehâ lutf u visâl

Su ile gelen hâller safâ (gönül şenliği, duruluk, itminan), sehâ (cömertlik), lütuf (yumuşaklık, nezaket, okşayış, iltifat) ve visâldir (kavuşma, murada eriş). Toprak, su ile hayat bulur. Su, göğün yere iltifatıdır. Yer, onunla muradına ulaşır. Rüzgâra gelince, o heva ve heves kaynağıdır:

Yil ile geldi bile bil dört heves

Ol durur kibr ü riyâ tizlik nefes

Rüzgârla gelen heveslerin ilki kibirdir. Kibir, son kertede, insanoğlunun ilahlaşma eğilimidir. Gücünün yettiklerine diz çöktürme, onların aşağılanmasından büyüklük vehmi devşirme psikolojisi. İkinci heves riyâdır ; ikiyüzlülük, hatta çok yüzlülük. Üçüncü heves tizlik (acelecilik), dördüncüsü ise nefestir. Nefesin buradaki anlamının uzun ve boş söz olduğunu zannediyorum. Yunus Emre başka bir şiirinde şöyle diyordu:

Kelecilerin bişirgil

Yaramazını şeşirgil

Sözün us ile düşürgil

Dimegil çoğ ide bir söz.

(Kelimelerini pişir, yaramazlarını ayır, sözünü akıl süzgecinden geçir ve işi uzatacak sözden uzak dur. Bazı okuyuşlarda çağada diye geçiyor ki çocukça veya düşüncesizce anlamına geliyor.)

Odıla geldi bile dört dürlü dad

Şehvet ü kibr ü tama' birle hased

Evet, bunlar da ateşle gelen çeşniler: Şehvet, kibir, tamah ve haset. Şehvet malum, kibir üzerinde kısaca durduk. Tamah ve haset (açgözlük ve kıskançlık), modern hayatın dingil çivileri. Dinlerin terbiye etmeye çalıştığı 
bu iki niteliğin 'normalleştirilmesiyle' Kapitalizm vücut buldu. Yunus'tan son bir beyit:

Cânıla geldi bile uş dört hisâl

İzzet ü vahdet hayâ âdâb-1 hâl

Dört unsurun birleşiminden ortaya çıkan cisme ilahî 'üfleyişle' oluşan cân da dört hasletle geliyor: İzzet, vahdet, hayâ ve edep. Bu hasletlerle süslenmeyen cân, beşer sayılsa da, insan sayılmıyor! Görüyorsunuz, sağlıklı bir medeniyet muhasebesi, belki Sorokin'in ülkücü (idealistic) diye nitelendireceği bir 'Gelenek' olmadan yapılamıyor. Sensate (duyusal) Batı'nın Yunus'ları ne kadar çırpınsa, Aydınlanma cenderesinden kurtulamıyor; Yaratıcı'nın kalbimizdeki sesine kulak vermek yerine, kurtuluşu kendi yarattıkları robotlara teslimiyette buluyor.

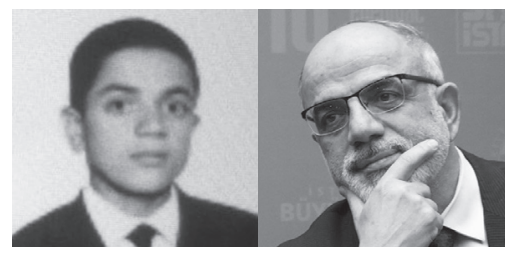

Mustafa Özel

\section{Kaynakça}

"Bob Dylon, in his own words" (15 Haziran 2020). The New York Times.

Cazenave, M. (1998). Dictionnaire de l'ignorance. Paris: Albin Michel.

Chomsky, N. (Nisan 2020). Coronavirus-What is at stake?. Diem25.

Daniel, A. M. (2020, 13 Haziran). The Verdict on Rough and Rowdy Ways by Bob Dylan: A Record We Need Right Now. Hot Press.

Galbraith, J. K. (1980). The Nature of Mass Poverty. Middlesex: Penguin.

Kutlar, A. (1986). Bediüzzaman Said Nursînnin Iktisadî Görüșleri, İstanbul: Tebliḡ.

McNeill, W. H. (1992). The Global Condition. Princeton: Princeton University Press.

McNeill, W. H. (1983). The Pursuit of Power. Oxford: Basil Blackwell.

Mills, C. W. (1970). The Sociological Imagination. Middlesex: Penguin, 1970.

Myrdal, G. (1972). Against the Stream. New York: Pantheon Books.

Rand, A. (1962). Capitalism: The Unknown Ideal. New York: New American Library.

Sanderson, S. K. (1995). Civilizational Approaches to World-Historical Change. S. K. Sanderson (ed.). Civilizations and World Systems. İçinde (s.18-19).Walnut Creek: Altamira.

Schwabb, K. (2020, 3 Haziran). Kapitalizme ‘Büyük Reset' atmanın zamanı geldi. Dünya.

Truong, N. (2020, 20 Mayıs). Philippe Descola: Nous sommes devenus des virus pour la planete. Le Monde. (çev. Haldun Bayrı). 


\title{
Dünyayı Üzdükleri İçin
}

\author{
Giy giy Korona \\ Ben eldivenli \\ Ve maskeli \\ Sen olduğun gibi \\ Gir koluma \\ Korkusundan \\ Girmedi oyuna
}

Söyle niçin bunca

Korkuttun

İnsanları?

Duyuldu

Ürkek bir ses

-Dünyayı üzdükleri için

Mustafa Ruhi Şirin 